SHS Web of Conferences 10, 00048 (2014)

DOI: $10.1051 /$ shsconf $/ 20141000048$

C Owned by the authors, published by EDP Sciences, 2014

\title{
Belief in the paranormal and modern health worries
}

\author{
A. Utinans and G. Ancane \\ Rīga Stradiòš University, Latvia
}

\begin{abstract}
It has been found, that despite the improvement of the objective health indicators, people's subjective perception of health is that health indicators are getting worse (Barsky A.J., 1988), which is one of the reasons why a new term "modern health worries" is coming into use in medical literature (Petrie K.J., Wessely S., 2002). People are worried and scared of the effect of new high tech innovations (effect of cell phone radiation, environmental pollution, ozone layer depletion, etc.), changes in manufacturing of food products (genetically modified food, food concentrates etc.). Nowadays, many people, being worried about their health, turn to new eating habits (veganism), defend themselves against various innovations in the health system (vaccination), etc. It could be defined as fear of consequences of scientific progress. The reason of fear is not only the misunderstanding of scientific innovations. Quite often, it is a belief in pseudoscientific theories (for example, "conspiracy") or belief in the paranormal phenomena (karma violations, disruption of the cosmic plan). In a part of cases protesters against vaccines and genetically modified food belong to new religious movements which are based on belief in the paranormal and magical thinking. Magical thinking predisposes to the negative attitude towards scientific assumptions and innovations, like a genetically modified food (Saher, 2006).

Aim of study. To study the correlation between pseudoscientific assumptions, belief in the paranormal and modern health worries. This condition of modern health worries is becoming important for health care system. It causes the increase in the number of symptoms (Koteles et al., 2011), which, in its turn, increases the doctors' visit rate on one hand (Rief W et al., 2012), but, on the other hand, increases evasion to attend traditional medical care activities. Part of supporters of pseudoscientific beliefs experiences anxiety as to the bad food toxins accumulating in the body and undertake unnecessary procedures, like an excessive detoxication of the body by means of enema. Some are of the opinion that meat promotes aggressiveness, while different esoteric theories advise to develop peacefulness and altruism. Consumption of meat can be addressed to as an offense against cosmic morality and karma. Part of supporters of pseudoscientific theories considers scientifically-educated doctors as wreckers, the disinterested, persons who are financially interested in orders of commercial firms and therefore entrust the treatment of even serious diseases to alternative medicine specialists (SKDS, 2012). Turning to unconventional, magical medicine is promoted also by the fact, that part of the people who believe in the magic, view the "healing energy" as being more "natural" and harmless. Functional somatoform disorders, due to modern health worries, can also be "healed" by specialists of unconventional medicine. Since the emotional factors are decisive in the etiopathogenesis of these symptoms, the unconventional medical approach promotes the decrease of functional symptoms. A vicious circle develops - belief in the magic and the paranormal things causes symptoms, at the same time the belief in the magic alleviates the same symptoms. As $a$ result, a literature review was done on the interrelationship of pseudoscientific assumptions and health worries. Conclusion. When treating the patients worried about their health, one has to take into account the aspects of complicated subjective perception, including belief in paranormal phenomena, pseudoscientific theories and prevalence of magical thinking.
\end{abstract}

This is an Open Access article distributed under the terms of the Creative Commons Attribution License 4.0, which permits unrestricted use, distribution, and reproduction in any medium, provided the original work is properly cited. 
SHS Web of Conferences

\section{Introduction}

"A paranormal belief is defined on a working basis as a proposition that has not been empirically attested to the satisfaction of the scientific establishment but is generated within the nonscientific community and extensively endorsed by people who might normally be expected by their society to be capable of rational thought and reality testing" (Irwin, H.J., 2009).

This definition has the merit of reflecting the important diversity of the beliefs that fall into this category, while excluding idiosyncratic beliefs, demonstrably psychotic delusions and developmentally immature beliefs, and scientific hypotheses awaiting empirical evaluation (Irwin, H.J., 2009). Irwin surveys the so-called paranormal beliefs in order to distinguish the categories, encompassed by such a term:

1. superstitions,

2. psi beliefs,

3. divinatory arts,

4. esoteric systems of magic,

5. New Age therapies,

6. spiritism,

7. eastern mystico-religious beliefs,

8. Judeo-Christian religious beliefs,

9. extraterrestrial aliens,

10. cryptozoological creatures.

Pseudoscientific belief has been defined as "A pretended or spurious science; a collection of related beliefs about the world mistakenly regarded as being based on scientific method or as having the status that scientific truths now have," (Oxford English Dictionary, second edition 1989).

Examples of pseudoscientific beliefs:

- Extraterrestial life (UFO impact on Earth, attacking humans);

- Cryptids; Cryptozoology (Bigfoot; Chupacabra);

- Pseudoscientific psychological theories (widespread postabortion guilt);

- Pseudoscientific sociological theories (conspiracy);

- Pseudoscientific biological theories (all GMO causes cancer).

It has been found that, despite the improvement of the objective health indicators, people's subjective perception of health is that health indicators are getting worse (Barsky A.J., 1988), which is one of the reasons why a new term "modern health worries" is coming into use in medical literature (Petrie K.J., Wessely S., 2002). Modern health worries (MHW) are the concerns related to modern or technological features of daily life (e.g., air pollution, x-rays, food additives, chemicals in household products, etc.), and have been associated with subjective health complaints (SHC) and health care use (K.B. Filipkowski et al, 2009). Modern health concerns may drive the perception of routine daily symptoms as physiological consequences of environmental factors. This has been suggested as being exacerbated by the media's overemphasis of high-risk and disease-related stories (K. Frost et al., 1997, B. Hofmann, 2009). Such focus increases the peculiarity of relatively rare events and can lead to the overestimation of its actual occurrence (T. Gilovich et al., 2002). Thus, people seeking explanations for perceived health complaints may make a connection between these modern hazards and their symptoms (Petrie K.J., Wessely S., 2002, Petrie K.J. et al., 2005).

People are worried and scared of the effect of new high tech innovations (effect of cell phone radiation, environmental pollution, ozone layer depletion, etc.), changes in manufacturing of food products (genetically modified food, food concentrates, etc.). Nowadays many people, being worried about their health, turn to new eating habits (veganism), defend themselves against various innovations 


\section{Int. Conf. SOCIETY. HEALTH. WELFARE.}

of the health system (vaccination), etc. It could be defined as fear of the consequences of scientific progress. The reason of fear is not only the misunderstanding of scientific innovations. Quite often, it is a belief in pseudoscientific theories (for example, "conspiracy") or belief in the paranormal phenomena (karma violations, disruption of the cosmic plan). In a part of cases, those who protest against vaccines and genetically modified food belong to new religious movements, which are based on belief in the paranormal and magical thinking. Magical thinking predisposes to the negative attitude towards scientific assumptions and innovations, like a genetically modified food (Saher, 2006).

This condition of modern health worries is becoming important for health care system. It causes the increase of the number of symptoms (Koteles et al., 2011), which, in its turn, increases the doctors' visit rate on one hand (Rief W. et al., 2012), but, on the other hand, increases evasion to attend traditional medical care activities. Part of supporters of pseudoscientific beliefs experience anxiety as to the bad food toxins accumulating in the body, and undertake unnecessary procedures, like excessive detoxication of the body by means of enema. Some are of the opinion that meat promotes aggressiveness, while different esoteric theories advise to develop peacefulness and altruism. Consumption of meat can be addressed to as an offense against cosmic morality and karma. Part of supporters of pseudoscientific theories consider scientifically-educated doctors as wreckers, the disinterested, persons who are financially interested in orders of commercial firms and therefore entrust the treatment of even serious diseases to alternative medicine specialists (SKDS, 2012). Turning to unconventional, magical medicine is promoted also by the fact, that part of the people who believe in the magic, view the "healing energy" as being more "natural" and harmless. Functional somatoform disorders due to modern health worries can also be "healed" by specialists of unconventional medicine. Since the emotional factors are decisive in the etiopathogenesis of these symptoms, the unconventional medical approach promotes the decrease of functional symptoms. A vicious circle develops - belief in the magic and the paranormal causes symptoms, at the same time the belief in the magic alleviates the same symptoms.

\section{Hypothesis}

In general population, there exist many different paranormal and pseudoscientific beliefs concerning harm from new scientific advances, such as:

1. Genetically modified organisms (GMO);

2. Vaccines;

3. Antibiotics;

4. Microwaves;

5. Psychotropic drugs;

6. TV, internet;

7. Contraception.

\section{Method}

Review of key words and the analysis of the content of Latvian internet sites "E-mistika", "Emistēija.lv"; "Urantija.lv" Data reduction and display of ideas with paranormal or pseudoscientific beliefs about health threats.

\section{Aim of study}

To look for paranormal and pseudoscientific beliefs about new scientific products that could be perceived as health threats. To study the correlation between pseudoscientific assumptions, belief in the paranormal and modern health worries. 


\section{SHS Web of Conferences}

\section{Results}

Most often mentioned scientific advance products that could cause health threats:

Vaccines;

GMO (GM food; GM crop);

Contraceptives;

Microchips;

Microwaves;

Antibiotics, psychotropic or other drugs;

Dental fillings.

The study managed to locate in internet sites such paranormal beliefs:

- Technical and pharmaceutical products have harmful effects because they are irradiating unhealthy rays.

- Microwaves destroy product's life energies by $90 \%$.

- Homeopathy is more natural ("Similia similibus curentur); pharmacy alienates from the natural medication and is harmful to the organism.

- Vital energies of natural products do not harm but heals the organism.

- GMO does not possess vital energy being not alive.

- GM foods destroy spiritual energy.

- It is morally wrong to counter rules of the Universe.

- It is dangerous to counter rules of Natural Order.

- We must not play the role of the God.

- Pseudoscientific beliefs- Conspiracy theories.

Medical doctors are:

- villains;

- disinterested in patients;

- persons financially interested in the orders of commercial firms;

- involved in global conspiracy to destroy and extinguish people from the planet.

The study managed to locate in internet sites such kind of conspiracy theories:

Harmful effects of vaccines and GMO are:

- Ignored by conservative politicians.

- Intentionally concealed for financial benefits.

- Used for "Social Violence and Criminality".

- Intentionally concealed in order to destroy and extinguish 5 million people from the planet depopulation.

- Used for controlling the mind- lies, deceptions, falsifications of statistics, brain washing by propaganda and turning people into zombies.

- Spanish flu was artificially created in secret laboratories for depopulation and dimishing of overcrowding.

- Vaccines were created to fight overcrowding.

- Quarantine would be used as a concentration camp in such a way annihilating the unwanted peoples. 
Int. Conf. SOCIETY. HEALTH. WELFARE.

The study found several pseudoscientific dramatizations:

- In US, every year 3000 children die from vaccination in four days.

- Illness rates in our country catch up US because of GMO.

- Harm of the GMO and vaccines to the human organism is absolutely sure.

- Pharmaceuticals want "pharmagedon".

The study found several minimizations of problems with natural phenomena:

- A human dies from illnesses rarer than from vaccines.

- Illnesses are not as dangerous as the official propaganda says; organism cures itself naturally.

- GM crop is less fertile than the natural crop.

- Physicians fabricate illnesses; in reality, many illnesses do not exist (such as avian influenza; pig flu, even HIV).

- Impostors create vaccines against diseases that do not exist.

The study found several idealizations of natural products or alternative healing methods:

- Only natural and raw food heals and improves health.

- Nature (Cosmic Wisdom) is much cleverer in comparison to irresponsible science and scientists.

\section{Discussion}

We do not know the spread of paranormal and pseudoscientific beliefs concerning MHW in population, but some statistics show that Latvian population is strongly affected by some ideas:

The inquiry of the Ministry of Environmental Protection and Regional Development about GMO has found that from 37440 respondents $96 \%$ are against the use of GMO in food (more than 35000 respondents)

Studying the number of emails sent to each country's minister, it was found that from 34119 emails Latvia sent 16 043, whereas Lithuania - 4 390, Estonia - 23, Finland - 276, France - 478, Sweden 217, United Kingdom - 254, but Germany -6 469. It is too much for Latvia.

The study was not organized to find out what kind of beliefs are used to provoke a greater number of health worries, and what kind of beliefs are not. A special assessment scale needs to be created in order to find the correlations between MHW and paranormal and pseudoscientific beliefs in general population.

When treating the patients who have health worries, one has to take into account the aspects of complicated subjective perception, including belief in paranormal phenomena, pseudoscientific theories and prevalence of magical thinking

The mentioned articles and films online on the danger of modern scientific advantages lack any scientific truth and critical thinking.

\section{Conclusion}

When treating the patients who have health worries, one has to take into account the aspects of complicated subjective perception, including the belief in paranormal phenomena, pseudoscientific theories and prevalence of magical thinking.

\section{References}

[1] Barsky A. J. The paradox of health // N Engl J Med 1988;318:414- 8.

$$
\text { 00048-p.5 }
$$


[2] Filipkowski K. B., Smyth J. M., Rutchick A. M. et al. Do Healthy People Worry? Modern Health Worries, Subjective Health Complaints, Perceived Health, and Health Care Utilization // International Society of Behavioral Medicine, 2009.

[3] Gilovich T., Griffin D., Kahneman D. Heuristics and biases: the psychology of intuitive judgment. New York: Cambridge University; 2002.

[4] Hofmann B. The paradox of health care // Health Care Anal. 2001;9:369-86.

[5] Irwin H. J. The Psychology of Paranormal Belief. A Researcher's Handbook. Hertfortshire: University of Hertforshire Press. 2009. -Pp. 16-17.

[6] Koteles F., Simon P. Modern Health Worries, Somatosensory Amplification and Subjective Symptoms: A Longitudinal Study: A Longitudinal Study. Int J Behav Med. 2013 Mar;20(1):38-41.

[7] Petrie K. J., Broadbent E. A., Kley N., et al. Worries about modernity predict symptom complaints after environmental pesticide spraying // Psychosom Med. 2005;67:778-82.

[8] Petrie K. J., Sivertsen B., Hysing M., et al. Thoroughly modern worries: the relationship of worries about modernity to reported symptoms, health and medical care utilization // J Psychosom Res. 2001;51:395-401.

[9] Petrie K. J., Wessely S. Modern worries, new technology, and medicine: new technologies mean new health complaints // Br Med J. 2002;324:690-1.

[10] Frost K., Frank E., Maibach E. Relative risk in the news media: a quantification of misrepresentation // Am J Public Health. 1997;87:842-5.

[11] Oxford English Dictionary, second edition 1989.

[12] Rief W, Hessel A, Braehler E. Somatization symptoms and

[13] hypochondriacal features in the general population. Psychosom Med

[14] 2001;63:595-602.

[15] Saher M., Lindeman M., Hursti U. K. Attitudes towards genetically modified and organic foods // Appetite, 2006 May;46(3):324-31.

[16] Vides aizsardzības un régionālās attīstības ministrijas komunikācijas nodaļa. Vairāk nekā 35000 iedzīvotāju ir pret ğgenētiski modificētiem organismiem Latvijā. http://www.varam.gov.lv/ lat/aktual/preses_relizes/?doc $=8436$ (sk. 03.04.2013.)

[17] SKDS, 2012. http://www.skds.lv/index.php?lng= lLat\&c= 2 (sk. 03.04.2013.)

[18] Stop the crop. http://gmo.zs-intern.de/stop-the-crop/ (sk. 03.04.2013.) 